\title{
The Vertical Distribution of Marine Macroplankton. III. Diurnal Observations on the Pelagic Young of Teleostean Fishes in the Plymouth Area.
}

\author{
By
}

\author{
F. S. Russell, D.S.C., B.A., \\ Assistant Naturalist at the Plymouth Laboratory.
}

With 8 Figures in the Text.

THIs paper records the results of two serial collections undertaken to obtain information on the behaviour of the post-larval stages of teleostean fish during the hours of darkness.

The net used was a stramin ring-trawl (2 metres diameter at mouth and 6 metres long). The first collections were taken on July 15th to 16th, 1924, at a period of full moon, at L4; on this occasion the hauls were so arranged that five series of collections were obtained between 3 p.m. on July 15 th and 11 a.m. on July 16th ; in each series samples were taken from five different depths. The second batch of samples was obtained on June 17th, 18th, and 19th, between L4 and the Eddystone. Samples were taken from six different depths in each series, and the experiment was carried through two successive nights. There was no moon.

The material was treated as described in a previous paper (6), all the young fish being picked out and then the remaining plankton organisms counted directly or by sampling. The results shown by the plankton organisms on July 15th to 16th, 1924, have already been published (6). It is unfortunate that on both occasions the numbers of post-larvæ of the more important food fish captured were very low. This was perhaps to be expected in 1924, as mid-July is somewhat late in the season to find the very young stages still in the plankton. On this account the collections in 1925 were made in the middle of June, at which time of the year in 1924 the young fish were very abundant. In 1925, however, for some unknown reason the post-larvæ of many species apparently disappeared from the plankton a month earlier than in $1924(\mathbf{y})$, and the results of the day and night collecting were most disappointing, the number of fish taken being considerably less even than in the series of collections taken on July 15th to 16th, 1924.

Table 1 gives the complete log taken on June 17th-19th, 1925 ; all times are Greenwich mean. (The log for July 15th to 16th, 1924, is given in a previous paper, 6.) 


\section{Table 1 .}

Date: June 17th-18th-19th, 1925. Position : between L4 and Eddystone. Ship : s.s. Salpa. Gear : 2-metre ring-trawl

\begin{tabular}{|c|c|c|c|c|c|c|c|c|}
\hline \multirow{7}{*}{$\begin{array}{l}\text { 1st Series } \\
\text { Brilliant sunshine; sea } \\
\quad \text { calm }\end{array}$} & \multirow{2}{*}{$\begin{array}{c}\text { Depth. } \\
\text { VI }\end{array}$} & \multicolumn{2}{|c|}{$\begin{array}{l}\text { Time net } \\
\text { entered water. }\end{array}$} & \multicolumn{2}{|c|}{ Fishing time. } & $\begin{array}{l}\text { Time net } \\
\text { left water. }\end{array}$ & $\begin{array}{l}\text { Length of } \\
\text { warp out. }\end{array}$ & \multirow[t]{7}{*}{ Remarks. } \\
\hline & & $2.33 \mathrm{~F}$ & p.m. & \multicolumn{2}{|c|}{$2.34 \frac{1}{2}-2.45 \frac{1}{2}$ p.m. } & 2.49 p.m. & 60 fathoms & \\
\hline & $\mathrm{V}$ & $2.57^{1}$ &, & $2.58-3.8$ & , & $3.10 \frac{1}{2}$, & $45 \quad$, & \\
\hline & IV & 3.20 &, & $3.21-3.31$ & , & 3.33, & 35 & \\
\hline & III & $3.39 \frac{1}{2}$ & , & $3.40-3.50$ &, & 3.51 & 20 & \\
\hline & II & - & & $4-4.10$ & , & - & 10 & \\
\hline & Surface & - & & $4.18 \frac{1}{2}-4.28 \frac{1}{2}$ & $\frac{1}{2}$, & - & 一 & \\
\hline \multirow{6}{*}{$\begin{array}{l}\text { 2nd Series } \\
\text { Sunset } 8.30 \text { p.m. ; } \\
\text { cloudless sky ; wind } \\
\text { freshening from } \\
\text { north ; sea slightly } \\
\text { loppy }\end{array}$} & VI & \multicolumn{2}{|c|}{$7.25 \frac{1}{2}$ p.m. } & $7.27-7.37$ & p.m. & 7.41 p.m. & 60 fathoms & \\
\hline & $\mathrm{V}$ & 7.49 & , & $7.50-8.0$ &, & $8.3 \frac{1}{2} \quad$, & $45 \quad$, & \\
\hline & IV & 8.12 & ", & $8.13-8.23$ & , & 8.25 & 35 & \\
\hline & III & 8.32 & , & $8.32 \frac{1}{2}-8.42 \frac{1}{2}$ &, & 8.44 & 20 & \\
\hline & II & - & & $8.53-9.4 \frac{1}{2}$ & , & - & 10 & \\
\hline & Surface & - & & $9.13-9.23$ & , & - & - & $\begin{array}{l}\text { Becoming difficult to read and see; } \\
\text { deck-lights on at } 9.30 \text { p.m. }\end{array}$ \\
\hline 3rd Series & VI & 10.37 & p.m. & $10.39-10.49$ & p.m. & 10.53 p.m. & 60 fathoms & Net struck bottom. Dark. \\
\hline \multirow{5}{*}{$\begin{array}{l}\text { No moon ; sea calm ; } \\
\text { wind freshening } \\
\text { from North as series } \\
\text { progressed }\end{array}$} & V & 11.10 & , & $11.11-11.21$ & , & $11.23 \frac{1}{2}$, & $45 \quad$, & Dark. \\
\hline & IV & 11.33 & , & $11.34-11.44$ & 1, & 11.46, & 35 & , \\
\hline & III & $11.54 \frac{1}{2}$ & $1 \frac{1}{2}$, & 11.55 p.m.- & -12.5 a.m. & 12.6 a.m. & 20 & , , \\
\hline & II & - & & $12.15-12.25$ & $5 \quad$, & - & 10 & When hauling 10 fathoms of wire \\
\hline & Surface & - & & $12.36-12.46$ & $6 \quad$, & - & - & were first run out by accident. \\
\hline \multirow{6}{*}{$\begin{array}{l}\text { 4th Series } \\
\text { Sun rose } 4.27 \text { a.m. ; } \\
\text { cloudless ; fresh } \\
\text { wind and slight lop }\end{array}$} & VI & $2.35 \mathrm{a}$ & a.m. & $2.36-2.46 \mathrm{a}$ & .m. & $2.48 \frac{1}{2} \mathrm{a} . \mathrm{m}$ & 60 fathoms & Towing rather fast. \\
\hline & V & 2.57 & , & $2.58-3.8$ &, & $3.10 \quad$, & $45 \quad$, & \\
\hline & IV & $3.18 \frac{1}{2}$ & , & $3.19-3.29$ & , & 3.30 & 35 & Getting light. \\
\hline & III & - & & $3.40-3.50$ & , & - & 20 & Deck-lights put out. \\
\hline & II & - & & $3.59-4.10$ & , & - & 10 & Light enough to read. \\
\hline & Surface & - & & $4.19-4.29$ & , & - & - & \\
\hline
\end{tabular}




\begin{tabular}{|c|c|c|c|c|}
\hline 5th Series & VI & 7.221 & a.m. & $7.241-7.34$ a.r \\
\hline Bright sunshine ; cloud- & $-V$ & $7.44 \frac{1}{2}$ &, & $7.45 \frac{1}{2}-7.55 \frac{1}{2}$ \\
\hline less sky ; fresh north & IV & $8.6{ }^{\circ}$ & $"$ & $8.6 \frac{1}{2} 8.16 \frac{1}{2}^{\alpha}$ \\
\hline wind & III & 8.26 & , & $8.26 \frac{1}{2}-8.36 \frac{1}{2}$ \\
\hline & II & - & & $8.45-8.55$ \\
\hline & Surface & 一 & & $9.2 \frac{1}{2}-9.14$ \\
\hline
\end{tabular}

6th Series VI 7.29 p.m. $7.30-7.40$ p.m.

Bright sunshine ; cloud- V 7.52 , $7.53-8.3$

less ; sea calm; sun- IV 8.11 , $8.11 \frac{1}{2}-8.23$,"

set 8.35 p.m. ; fresh III $8.30 \frac{1}{2}$, , 8.31-8.41 ,

north wind ; it had II - $\quad 8.49-8.59$,

been very fine and Surface - $\quad 9.6_{2}^{1}-9.16_{2}^{1}$,,

sunny all day

7th Series $\quad$ VI 10.31 p.m. 10.33-10.43 p.m.

No moon ; cloudless ; V 10.55, , $10.55 \frac{1}{2}-11.5 \frac{1}{2}$,

fresh north wind ; IV 11.15, , 11.16-11.26 ",

sea loppy

III - 11.36-11.46, ,

II $-\quad 11.55$ p.m.- $12.5 \mathrm{a} . \mathrm{m}$

Surface - 12.13-12.23 ,

8th Series

Sun rose 4.23 a.m. ; cloudless

VI 2.27 a.m. $\quad 2.28 \frac{1}{2}-2.38 \frac{1}{2}$ a.m.

V $2.48 \quad, \quad 2.49-2.59$,

IV $3.8, \quad 3.9-3.19$

III $3.28, \quad 3.28 \frac{1}{2}-3.38 \frac{1}{2}, "$

II $\quad-\quad 3.49-3.59$

Surface - $4.6 \frac{1}{2}-1.16 \frac{1}{2} \quad$,

9th Series

VI $7.32 \frac{1}{2}$ a.m. $7.35-7.45$ a.m.

Bright sunshine ; cloudless ; sea calm

$\begin{array}{lllll}\text { V } & 7.55 & , & 7.56-8.6 & , \\ \text { IV } & 8.15 & , & 8.15 \frac{1}{2}-8.25 \frac{1}{2} & , \\ \text { III } & 8.34 \frac{1}{2} & , & 8.35-8.45 & , \\ \text { II } & - & & 8.53 \frac{1}{2}-9.3 \frac{1}{2} & , \\ \text { Surface } & - & & 9.11 \frac{1}{2}-9.21 \frac{1}{2} & ,\end{array}$

$7.36 \frac{1}{2}$ a.m. 60 fathoms

$7.57 \frac{1}{2},, \quad 45 \quad$,

$8.17 \frac{1}{2}, \quad 35 \quad, \quad$ Clouding over ; thin flakes.

$8.37,20 \quad, \quad$ Clouds dispersing.

- $\quad 10 \quad, \quad$ Sun shining all time.

- - -

7.43 p.m. 60 fathoms

$8.4 \frac{1}{2},, 45 \quad$,

$8.24,, \quad 35$, ,

$8.42, \quad 20$, ,

- $10 \quad, \quad$ Getting hard to see.

- $\quad$ D Deck-lights on.

10.46 p.m. 60 fathoms Dark.

$11.7, \quad 45$,

$11.27, \quad 35,$,

- 20 ,

- 10 ,

2.41 a.m. 60 fathoms

$3.1 \frac{1}{2}, 45 \quad$,

$3.20 \frac{1}{2},, \quad 35 \quad, \quad$ Getting light.

3.39 , 20 ,

- $10 \quad, \quad$ Deck-lights put out.

- $\quad-$

$7.47 \frac{1}{2}$ a.m. 60 fathoms

$8.7 \frac{1}{2},, 45 \quad$,

$8.27, \quad 35$,

$8.45 \frac{1}{2},, 20$, 


\section{The Fishing Depths.}

On both occasions the depth-recorder, kindly lent by Admiralty Authorities, was in use and tracings were obtained of the actual path of the net through the water for each haul; the tracings for the 1924 collections have been reproduced in the previous paper (6).

In 1924 the results were very satisfactory in that they showed that for most hauls the net fished steadily at the required depths, and did not follow an irregular course up and down through the water; also the net fished at approximately the same five depths in each series; it is, however, regrettable that no samples were obtained from the water layers between 34 metres and the bottom, at $51 \mathrm{~m}$. In 1925 the depth records showed very unfavourable fishing results compared with the above. The first two series were satisfactory, but at midnight on the first night a misfortune occurred; in our efforts to get the net into the deeper layers it struck the bottom. Thereafter the results obtained by the recorder reflected the uneasiness felt by the collector, and show that the speed of the ship when towing had been increased slightly in order to avoid the possibility of a re-occurrence of the accident. As a result, as in 1924, there are no samples in the remaining six series from the water layers between 32 metres and the bottom. This is unfortunate, as we shall see when we come to consider the vertical distribution of the various species of young fish captured.

A fresh attempt to repeat the experiment will be made, this time, if possible, in May, to ensure a good supply of fish; efforts also will be made to obtain more samples from the deeper layers. This is necessarily somewhat risky; the use of the depth-recorder has shown that it is a common occurrence for the net to traverse a vertical distance of 10 or more metres in its path through the water, and that hence in the deeper water layers the possibilities of the net striking bottom at some particular instant during the haul are great; the large amount of sand brought up by the net on such an occasion cannot but be detrimental to the material of which the net is made.

The tracings obtained in June, 1925, are reproduced in Figs. 1 and 2. It can be seen that in the 3rd and 4th series the clock of the recording drum ran down after a very short time, so that in hauls III and IV of the 3rd series and II and III of the 4th series the maximum depth only was recorded. This was rectified when it became light enough to examine the clock, and it was found that the error was due to the slipping of the winding key which had become worn ; for the remainder of the collections the clock was wound by means of a pair of pliers.

The average depths have been estimated as previously described in another paper (6), by taking the depth at ten equidistant points along 
the curve and calculating the mean. The sudden increase in depth of the net at the end of haul II of the third series was due to the several fathoms of warp being accidentally allowed to run off the winch drum immediately before hauling in.

Table 2 gives the average depth for each haul.

\section{TABLE 2 .}

Average Depth in Metres for each Haul ON JunE 17TH-18TH-19TH, 1925.

$\begin{array}{lccccccccc} & \begin{array}{c}\text { 1st } \\ \text { Series. }\end{array} & \begin{array}{c}\text { 2nd } \\ \text { Series. }\end{array} & \begin{array}{c}\text { 3rd } \\ \text { Series. }\end{array} & \begin{array}{c}\text { Sth } \\ \text { Series. }\end{array} & \begin{array}{c}5 \text { th } \\ \text { Series. }\end{array} & \begin{array}{c}6 \text { th } \\ \text { Series. }\end{array} & \begin{array}{c}7 \text { th } \\ \text { Series. }\end{array} & \begin{array}{c}\text { 8th } \\ \text { Series. }\end{array} & \begin{array}{c}\text { Sth } \\ \text { Series. }\end{array} \\ \text { II } & - & - & - & - & - & - & - & - & - \\ \text { III } & 4 \cdot 5 & 5 \cdot 4 & 11 \cdot 2 & 6 * & 3 \cdot 2 & 3 \cdot 2 & 5 \cdot 2 & 3 \cdot 6 & 4 \\ \text { IV } & 16 \cdot 2 & 14 & 23^{*} & 13^{*} & 7 \cdot 5 & 9 \cdot 3 & 12 \cdot 2 & 8 & 11 \cdot 1 \\ \text { V } & 23 \cdot 4 & 24 \cdot 8 & 31 * & 18 & 9 \cdot 9 & 14 & 16 \cdot 6 & 13 \cdot 9 & 12 \cdot 7 \\ \text { VI } & 29 \cdot 8 & 31 \cdot 3 & 29 & 26 \cdot 8 & 20 \cdot 8 & 19 \cdot 4 & 20 \cdot 7 & 23 \cdot 7 & 23 \cdot 3 \\ \text { VI } & 48 \cdot 8 & 38 \cdot 6 & 49 & 30 & 31 \cdot 4 & 30 \cdot 9 & 25 \cdot 8 & 27 \cdot 5 & 28 \cdot 5\end{array}$

General Results.

In Tables 7 and 8 (pp. 397-399) are given the actual numbers of each species taken in the collections. In most cases reference is made to these two tables when discussing the results for each species in detail.

This work must be regarded merely as a record of the behaviour of the various species of post-larval fish on the three nights in question, one night of which was at the time of full moon while the other two were moonless.

On all occasions the majority of species showed only a very slight movement at night. There were, however, one or two exceptions, notably the post-larvæ of Sardina pilchardus, which became much more abundant at night, curiously enough at all depths. The reasons for this increase in numbers shown by the post-larval pilchard are, at the moment, not quite clear; further observations are needed. There was also evidence that certain species, e.g. Callionymus lyra, showed a behaviour on the moonlight night different from that on the dark nights with no moon. On the moonlight night Callionymus showed no signs of upward movement, whereas on the two dark nights their distribution stretched upwards to the surface.

As regards the night of July 15th to 16th, 1924, a study of Table 7 conveys the impression that at night there was only a slight filling up of the surface layers, in which the post-larvæ were comparatively scarce

* Maximum depth only. 
METRES.

METRES.
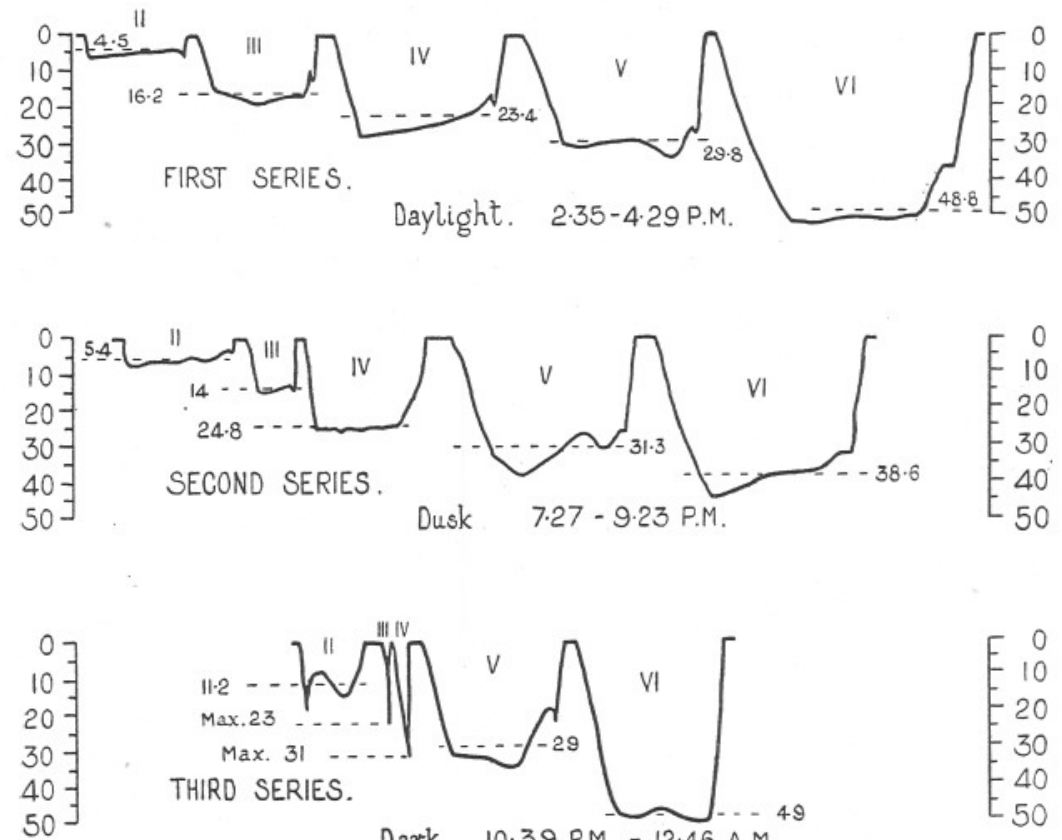

Dark. 10.39 P.M. -12.46 A.M
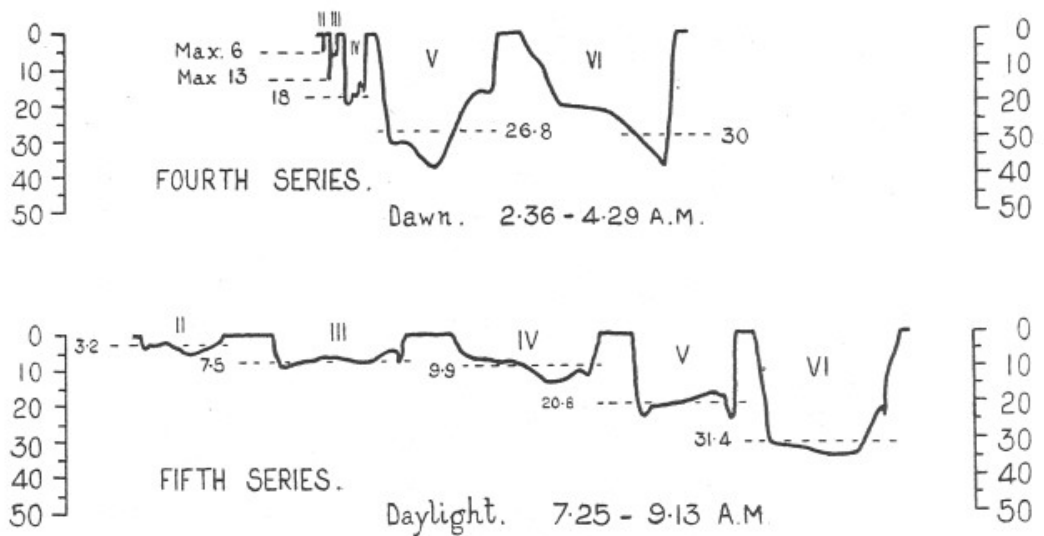

FIG. 1.-The first five series of curves given by the depth recorder indicating the path of the net through the water at five depths during the collections of June 17th-18th19th, 1925. (The surface haul is not included.) The net enters the water on the right-hand side of each curve. The dotted lines indicate; the calculated "average depths." 
in the daytime, with no consequent marked diminution of numbers of fish in the deeper layers.

Table 3 gives the total numbers of young fish taken in each haul without those of Sardina pilchardus and Gobius elongatus, the post-larvæ of which species were so numerous that they would distort the true picture of events. Table 4 gives the numbers of different species of fish post-larvæ taken in each haul.

METRES.

METRES.
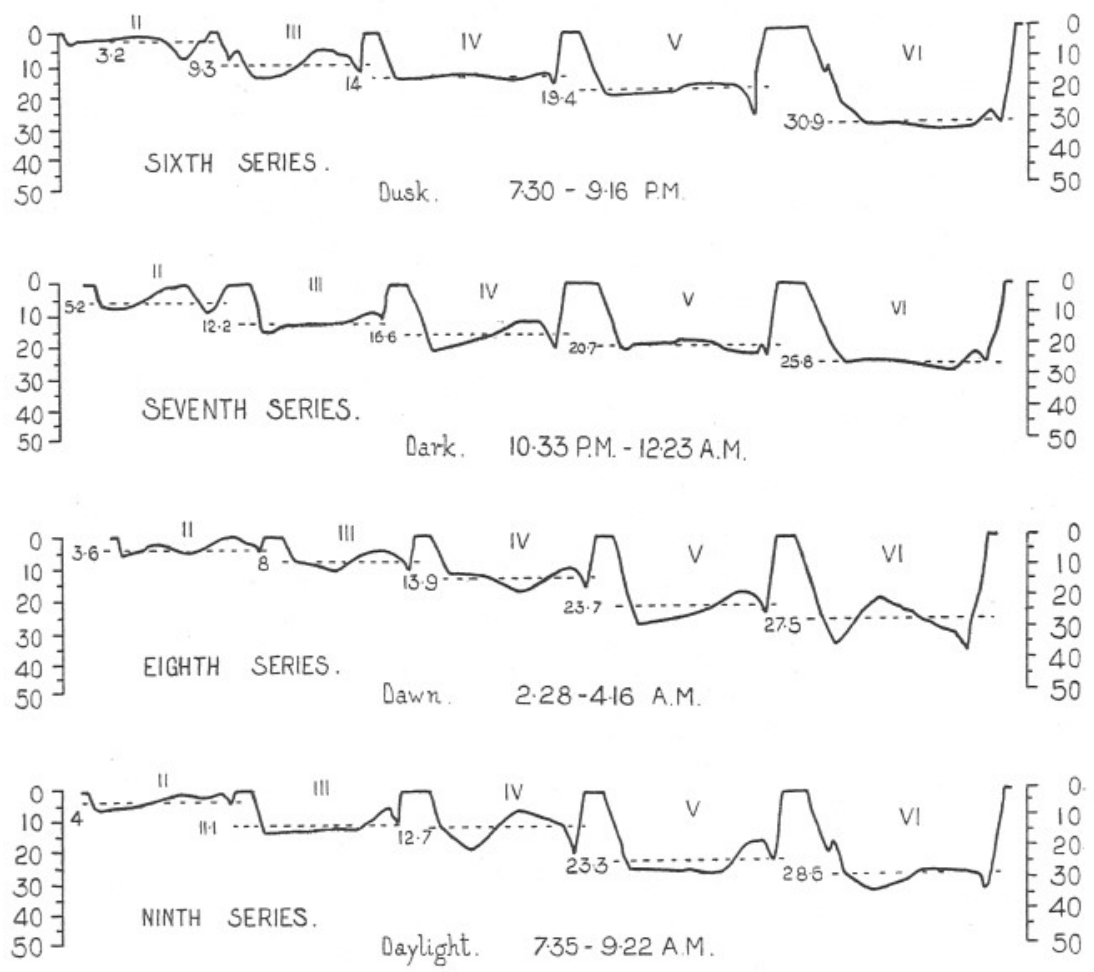

FIG. 2.-The last four series of curves given by the depth recorder indicating the path of the net through the water at five depths during the collections of June 17th-18th-19th, 1925. (The surface haul is not included.) The net enters the water on the right-hand side of each curve. The dotted lines indicate the calculated "average depths."

It will be seen from Table 4 that there were definitely more species of young fish present at the surface at night than at any other time ; this agrees well with the findings of Johansen in Danish waters $(4, \mathrm{p} .6)$. In the lower layers from about 9 metres downwards there would not appear to be much change, an obvious increase at night in the deepest layer $(\mathrm{V})$, being somewhat compensated by a decrease in the layers above (IV). 
TABLE 3 .

Total Numbers of Post-larva caught in each Haul on July 15th16TH, 1924, EXCLUSIVE OF THOSE OF SARDINA PILCHARDUS AND Gobius elongatus.

\begin{tabular}{|c|c|c|c|c|c|}
\hline & $\begin{array}{l}\text { 1st Series. } \\
3.25 \text { p.m. to } \\
4.45 \text { p.m. }\end{array}$ & $\begin{array}{l}\text { 2nd Series. } \\
7.55 \text { p.m. to } \\
9.17 \text { p.m. }\end{array}$ & $\begin{array}{l}\text { 3rd Series. } \\
10.50 \text { p.m. to } \\
12.20 \text { a.m. }\end{array}$ & $\begin{array}{l}\text { 4th Series. } \\
2.50 \text { a.m. to } \\
4.16 \text { a.m. }\end{array}$ & $\begin{array}{l}\text { 5th Series. } \\
8.45 \text { a.m. to } \\
10.11 \text { a.m. }\end{array}$ \\
\hline Surface & 9 & 8 & 52 & 14 & 14 \\
\hline II, $2-7 \mathrm{~m}$. & 44 & 46 & 61 & 43 & 30 \\
\hline III, 9-15 m. & 87 & 48 & 61 & 121 & 82 \\
\hline IV, $16-20 \mathrm{~m}$. & 286 & 172 & 61 & 77 & 172 \\
\hline $\mathrm{V}, 30-34 \mathrm{~m}$. & 56 & 211 & 149 & 153 & 106 \\
\hline Total & 482 & $\overline{485}$ & $\overline{384}$ & $\overline{408}$ & $\overline{404}$ \\
\hline
\end{tabular}

TABLE 4 .

Total Numbers of different Species of Fish Post-larve occurring in the Collections made on July 15̆TH-16Th, 1924.

\begin{tabular}{|c|c|c|c|c|c|}
\hline & $\begin{array}{l}\text { 1st Series. } \\
3.25 \text { p.m. to } \\
4.45 \text { p.m. }\end{array}$ & $\begin{array}{l}\text { 2nd Series. } \\
7.55 \text { p.m. to } \\
9.17 \text { p.m. }\end{array}$ & $\begin{array}{l}\text { 3rd Series. } \\
10.50 \text { p.m. to } \\
12.20 \text { a.m. }\end{array}$ & $\begin{array}{l}\text { 4th Series. } \\
2.50 \text { a.m. to } \\
4.16 \text { a.m. }\end{array}$ & $\begin{array}{l}5 \text { th Series. } \\
8.45 \text { a.m. to } \\
10.11 \text { a.m. }\end{array}$ \\
\hline Surface & 7 & 6 & 16 & 3 & 7 \\
\hline II, $2-7 \mathrm{~m}$ & 14 & 15 & 16 & 11 & 9 \\
\hline III, 9-15 m. & 17 & 14 & 18 & 16 & 19 \\
\hline $\mathrm{IV}, 16-20 \mathrm{~m}$. & 22 & 22 & 15 & 16 & 18 \\
\hline $\mathrm{V}, 30-34 \mathrm{~m}$ & 11 & 15 & 20 & 17 & 14 \\
\hline
\end{tabular}

TABLe 5.

Total Numbers of Post-larva caught in each Haul on June 17th18TH-19TH, 1925, EXCLUSIVE OF THOSE OF SARDINA PILCHARDUS, Gobius elongatus, and Callionymus lyra.

\begin{tabular}{lrrrrrrrrr} 
& \multicolumn{9}{c}{ Dark. } \\
Series & 1 & 2 & 3 & 4 & 5 & 6 & 7 & 8 & 9 \\
Surface & 1 & 3 & 19 & 5 & - & 3 & 18 & 3 & 2 \\
II & 17 & 14 & 34 & 8 & 3 & 2 & 16 & 5 & 2 \\
III & 10 & 13 & 21 & 6 & 7 & 4 & 12 & 6 & 6 \\
IV & 22 & 13 & 17 & 19 & 5 & 15 & 25 & 20 & 13 \\
V & 70 & 38 & 15 & 15 & 5 & 23 & 64 & 26 & 26 \\
VI & 42 & 18 & & 14 & 6 & 56 & 31 & 25 & 28
\end{tabular}




\section{TABLE 6 .}

Total Numbers of different Species of Fish Post-larve occurring in the Collections made on June $17 \mathrm{TH}-18 \mathrm{TH}-19 \mathrm{TH}, 1925$.

\begin{tabular}{|c|c|c|c|c|c|c|c|c|c|}
\hline \multirow[b]{2}{*}{ Series } & \multicolumn{5}{|c|}{ Dark. } & \multicolumn{3}{|c|}{ Dark. } & \\
\hline & 1 & 2 & 3 & 4 & 5 & 6 & 7 & 8 & 9 \\
\hline Surface & 3 & 4 & 11 & 5 & 0 & 2 & 8 & 1 & \\
\hline II & 3 & 9 & 16 & 5 & 2 & 4 & 9 & 6 & \\
\hline III & 7 & 9 & 12 & 6 & 6 & 5 & 12 & 7 & \\
\hline IV & 7 & 8 & 11 & 12 & 5 & 11 & 13 & 10 & \\
\hline $\mathrm{V}$ & 10 & 14 & 12 & 11 & 6 & 8 & 18 & 12 & \\
\hline VI & 11 & 13 & & 13 & 5 & 12 & 17 & 12 & \\
\hline
\end{tabular}

In Tables 5 and 6 the results obtained on the nights, June 17th-18th19th, 1925, are dealt with in a similar manner, except that in Table 5, which gives the total numbers of post-larvæ taken in each haul, the post-larval Callionymus lyra have been excluded as well as Sardina pilchardus and Gobius elongatus.

Table 5 shows that on this occasion the results were somewhat similar to those obtained on July 15th-16th, 1924 ; the numbers are very small, but they show, if anything, perhaps that the upward movement was more marked on this occasion. Table 6 shows that there was a general increase in the number of species at all depths at night except at 29 metres at 11.11 p.m. on the first night.

In the following pages the vertical distribution of each species will be discussed in detail.

\section{CLUPEID $\nRightarrow$.}

\section{Sardina pilchardus (Walb.).}

If we examine the percentage distribution of Sardina pilchardus post-larvæ (Table 9) on July 15th-16th, 1924, we see that while tending to be most abundant between 10 and 20 metres in the daytime the young fish filled up the surface layers at dusk and midnight, and further, that at midnight more were taken actually at the surface than at any other depth. At dawn they left the surface, and the greatest number were taken at a depth of about 9 metres; in full daylight they had resumed almost exactly the same distribution as on the previous afternoon.

In addition to this evidence of change in the vertical distribution of the post-larvæ there is a very marked increase in the numbers caught 
at midnight and even more so at dawn. In fact, it would appear that we were at the time passing through a large shoal, and that at about 3 a.m. we encountered the densest region. This increase in numbers is illustrated in Fig. 3, which shows diagrammatically the actual number of individuals caught at the different depths in each series of hauls.

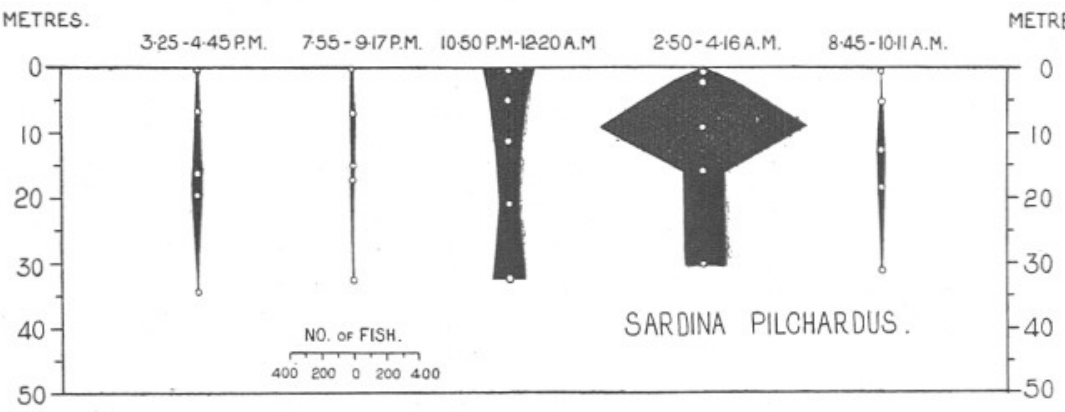

FIG. 3.-The vertical distribution of Sardina pilchardus post-larvæ, at the times shown, on July 15th-16th, 1924, showing the large increase in numbers at all depths at midnight and dawn. The white spots and black circles indicate the "average depths" at which hauls were taken.

In Table $10 \mathrm{I}$ give the number of post-larvæ of this species taken at the different depths in June, 1925.* Here again we see a tendency to extend into the upper layer at night, and again also we note an increase in the total numbers taken at night; although the figures are not so great as in 1924 this increase in numbers is very noticeable in the diagrammatic distribution shown in Fig. 4. On this occasion it is the night series only that show the largest catches; at dawn, between 2 and 4 a.m., there is an

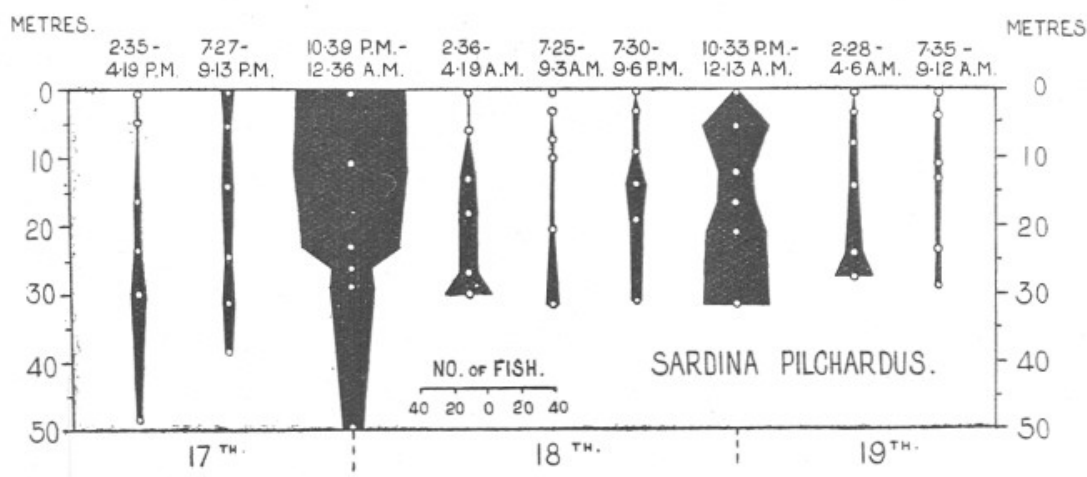

FIG. 4.-The vertical distribution of Sardina pilchardus post-larvæ, at the times shown, on June 17th-18th-19th, 1925, showing the large increase in numbers at all depths on the two nights. The white spots and black circles indicate the "average depths" at which hauls were taken.

* All the post-larvæ caught on this occasion were less than $20 \mathrm{~mm}$. in length. 
Table 7.

Young Fish Caught, July 15th-16th, 1924. Full Moon.

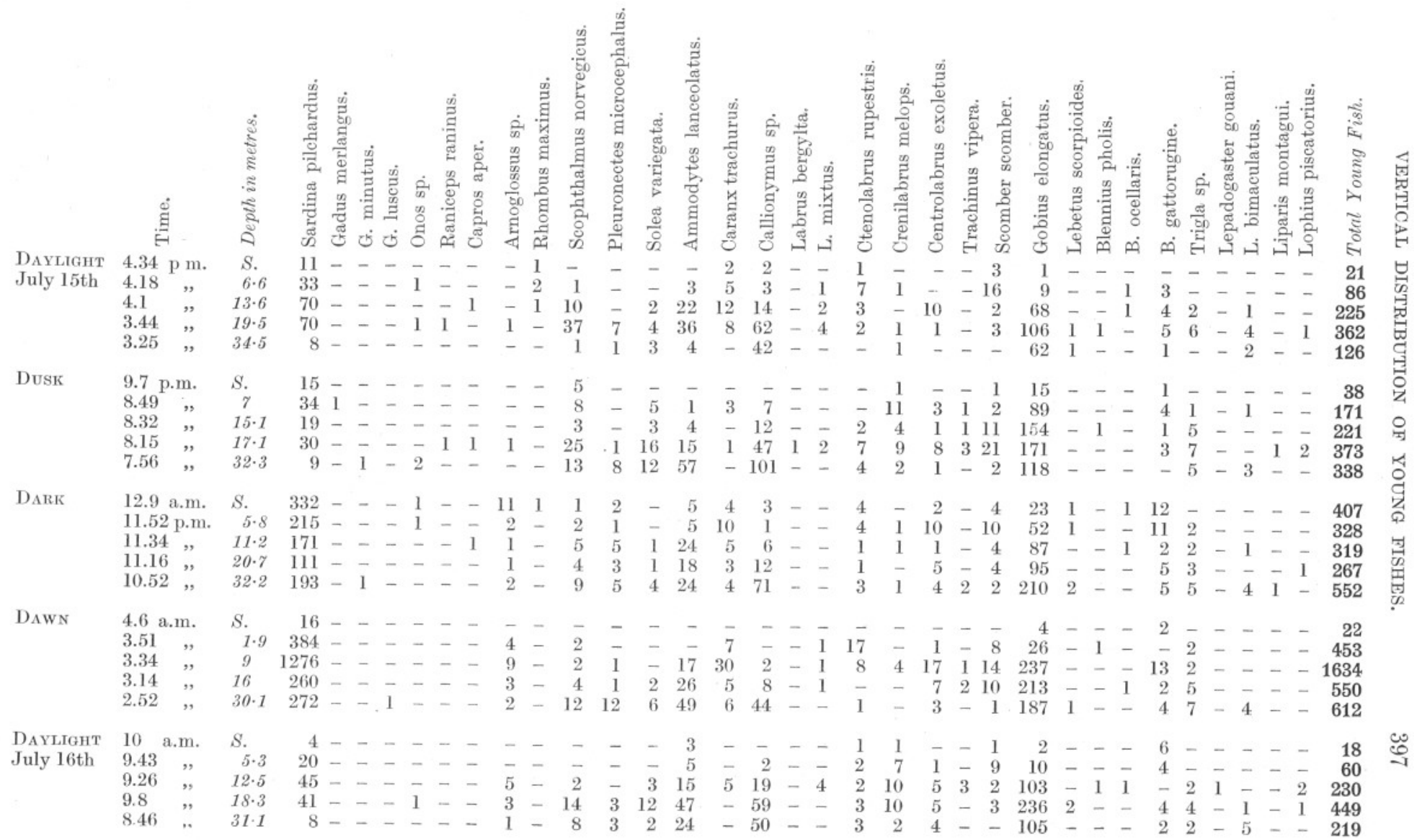


Young Fish CaUght, June 17тh-18тh-19Th, 1926. No Moon.
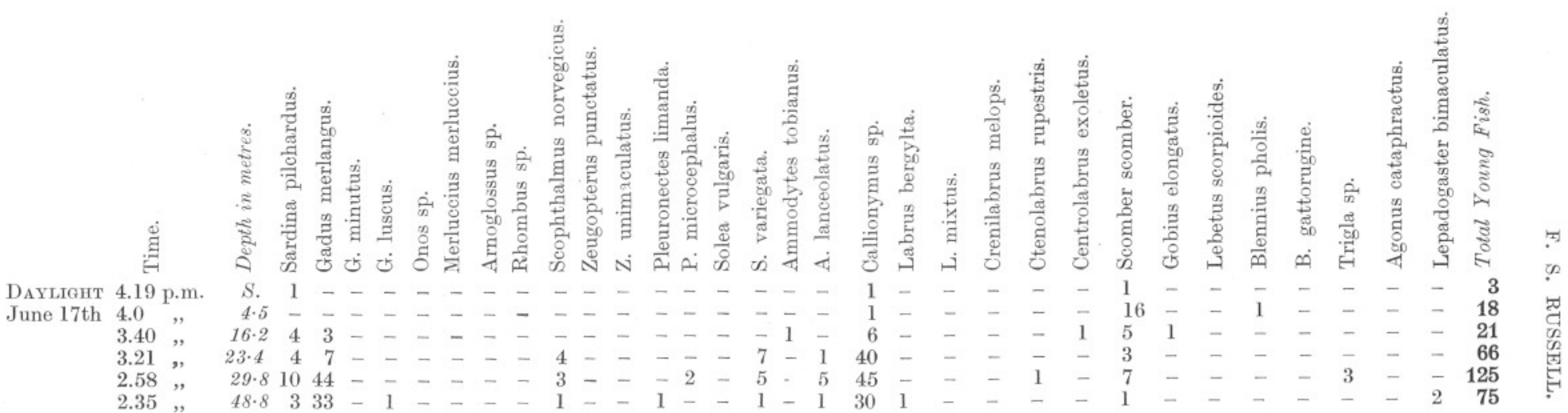

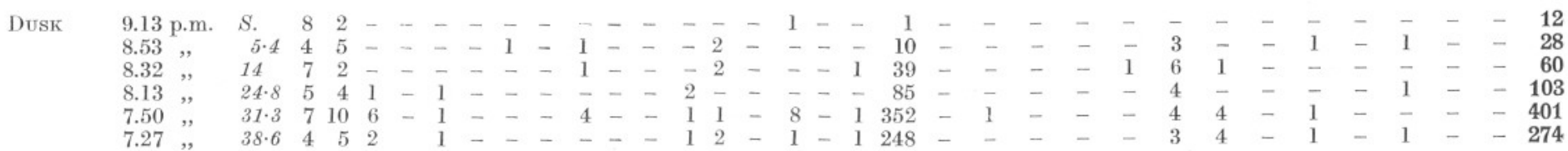

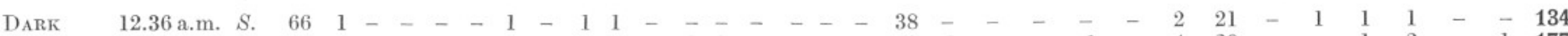

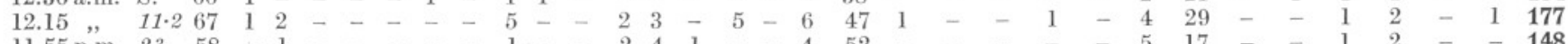

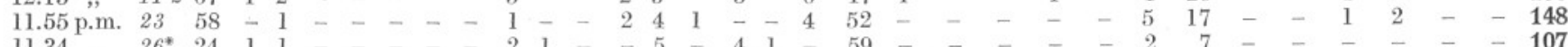

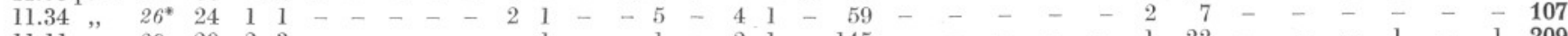
$\begin{array}{rrrrrrr}11.11 & \Rightarrow & 29 & 29 & 2 & 3 & -\end{array}$ 


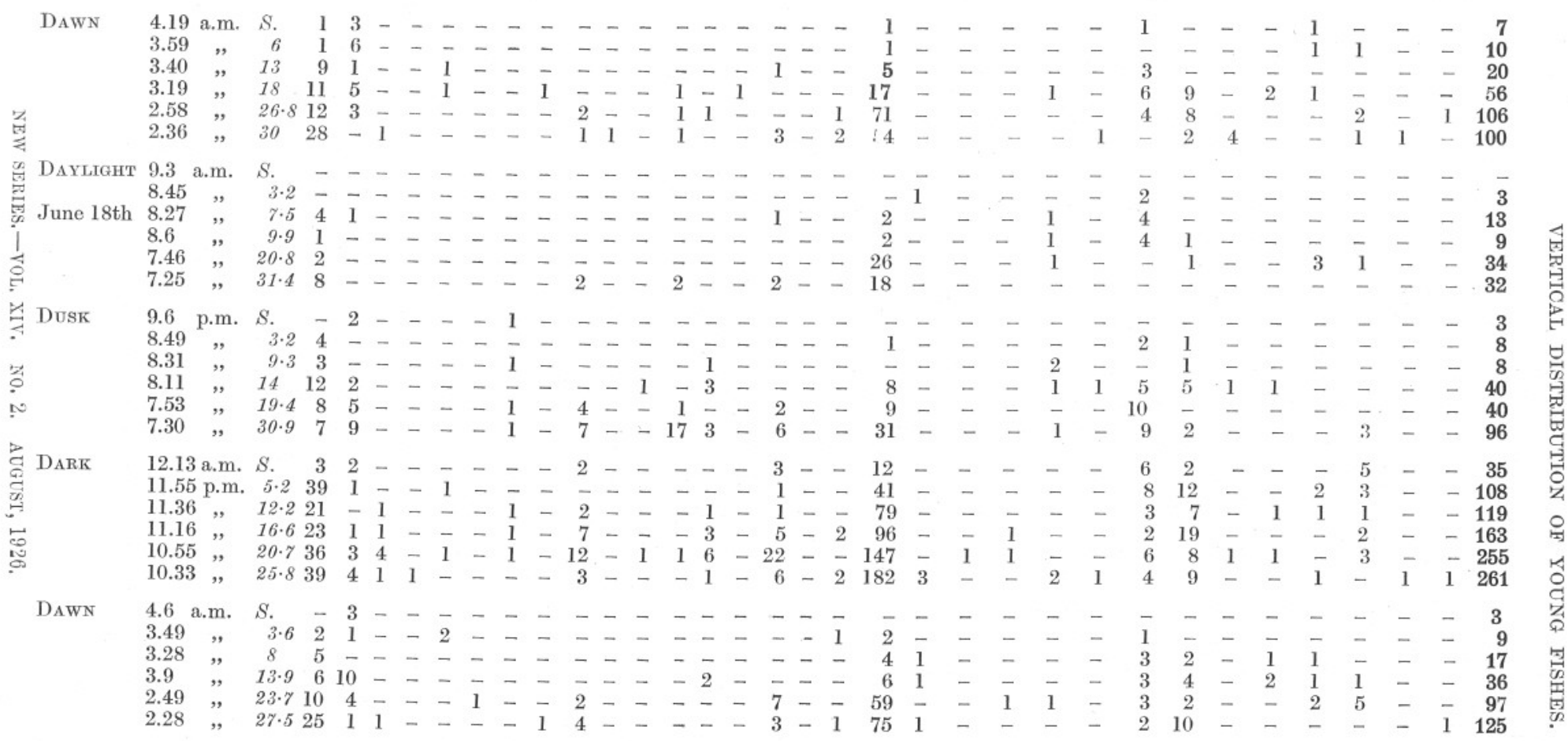

DAYLIGHT 9.12 a.m. S. $\quad$ - $-\ldots \ldots+\ldots$

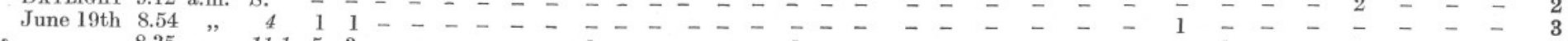

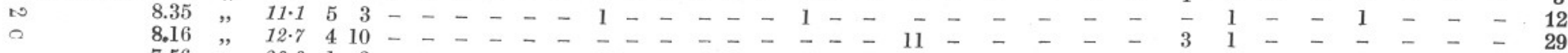

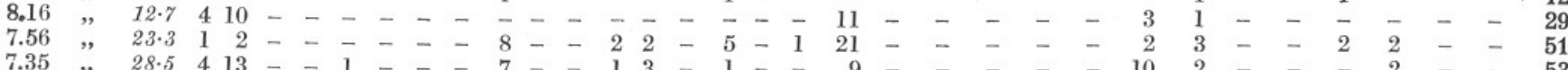

$\begin{array}{cccccc}7.35 \quad \Longrightarrow \quad 28.5 & 4 & 13 & - & - & \end{array}$ 
indication of increase in numbers in the bottom haul both on the 18th and the 19th; it is unfortunate that there are no deeper hauls to show whether they were even more abundant below. It is interesting to note TABLE 9.

Post-larve of Sardina pilchardus caught in the Ring-trawl on JuLY $15 \mathrm{TH}-16 \mathrm{TH}, 1924$.

\begin{tabular}{|c|c|c|c|}
\hline $\begin{array}{l}\text { Depth in } \\
\text { metres. }\end{array}$ & $\begin{array}{l}5-10 \\
\text { mm. }\end{array}$ & $\begin{array}{c}11-15 \\
\mathrm{~mm} .\end{array}$ & $\begin{array}{c}16-24 \\
\mathrm{~mm} .\end{array}$ \\
\hline
\end{tabular}

$\begin{array}{lcrrrrrr}\text { 1st Series } & \text { Surface } & - & 11 & - & - & 11 & 5 \cdot 7 \\ \text { 3.25- } & \text { II } & 6 \cdot 6 & 33 & - & - & 33 & 17 \cdot 2 \\ \text { 4.45 p.m. } & \text { III } & 13 \cdot 6 & 60 & 10 & - & \text { r0 } & 36 \cdot 5 \\ \text { Daylight } & \text { IV } & 19 \cdot 5 & 61 & 7 & 2 & \text { r0 } & 36 \cdot 5 \\ & \text { V } & 34 \cdot 5 & 8 & - & - & 8 & 4 \cdot 1 \\ \text { 2nd Series } & \text { Surface } & - & 5 & 10 & - & 15 & 14 \cdot 1 \\ \text { 7.55- } & \text { II } & 7 & 23 & 11 & - & 34 & 31 \cdot 7 \\ \text { 9.17 p.m. } & \text { III } & 15 \cdot 1 & 11 & 7 & 1 & 19 & 17 \cdot 8 \\ \text { Dusk } & \text { V } & 17 \cdot 1 & 16 & 12 & 2 & 30 & 28 \cdot 1 \\ & \text { V } & 32 \cdot 3 & 4 & 2 & 3 & 9 & 8 \cdot 3 \\ \text { 3rd Series } & \text { Surface } & - & 160 & 156 & 16 & 332 & 32 \cdot 5 \\ \text { 10.50 p.m. } & \text { II } & 5 \cdot 8 & 141 & 66 & 8 & 215 & 21 \cdot 1 \\ \text {-12.20 a.m. } & \text { III } & 11 \cdot 2 & 124 & 31 & 16 & 171 & 16 \cdot 7 \\ \text { Dark } & \text { IV } & 20 \cdot 7 & 67 & 34 & 10 & 111 & 10 \cdot 8 \\ & \text { V } & 32 \cdot 2 & 142 & 41 & 10 & 193 & 19 \\ \text { 4th Series } & \text { Surface } & - & 16 & - & - & 16 & 0 \cdot 7 \\ \text { 2.50- } & \text { II } & 1 \cdot 9 & 326 & 57 & 1 & 384 & 17 \cdot 4 \\ \text { 4.16 a.m. } & \text { III } & 9 & 982 & 258 & 36 & 1276 & 5 \% \cdot 7 \\ \text { Dawn } & \text { IV } & 16 & 187 & 61 & 12 & 260 & 11 \cdot 8 \\ & \text { V } & 30 \cdot 1 & 173 & 91 & 8 & 272 & 12 \cdot 3 \\ \text { 5th Series } & \text { Surface } & - & 3 & 1 & - & 4 & 3 \cdot 3 \\ \text { 8.45- } & \text { II } & 5 \cdot 3 & 17 & 3 & - & 20 & 17 \cdot 0 \\ \text { 10.11 a.m. } & \text { III } & 12 \cdot 5 & 37 & 5 & 3 & \mathbf{4 5} & 38 \cdot 2 \\ \text { Daylight } & \text { IV } & 18 \cdot 3 & 29 & 8 & 4 & 41 & 34 \cdot 8 \\ & \text { V } & 31 \cdot 1 & 5 & 2 & 1 & 8 & 6 \cdot 7\end{array}$

that the catch actually at the surface at midnight on 18th-19th was very small. I This was also shown by certain other plankton organisms.

Now we have said that in 1924 there was a possibility that we might have run into a shoal of young pilchard at night; this might also be put 
forward as an explanation for the 1925 results. It would be a curious coincidence, however, if this has occurred on three occasions, and especially on two successive nights as it did in 1925. A further possibility would be that in the light the greatest numbers descend to below 30 metres or just above the bottom. There is no sign that such was the case in the first two series on June 17th, 1925, when we were fortunate enough to fish the net well down in the deeper layers. The question remains, did they escape the net on all occasions except in the dark? I do not think that young pilchard, all less than $20 \mathrm{~mm}$. in length, would be able to avoid so large a net as the ring-trawl, but on this question we need more observations. The only explanation that remains is the possibility of swarm formation by the small fish. If this were so one would expect that the swarm formation occurred in the daytime, when the small numbers caught could be accounted for by the fact that no swarms were encountered by the net.

It is obvious that it is of no avail to try and bring forward explanations of these curious results until we have far more observations.

Table 10.

Post-larve of Sardina pilchardus on June 17Th-18Th-19Th, 1925.

\begin{tabular}{|c|c|c|c|c|c|c|c|c|c|}
\hline \multirow[b]{2}{*}{ Series } & \multicolumn{5}{|c|}{ Dark. } & \multicolumn{4}{|c|}{ Dark. } \\
\hline & 1 & 2 & 3 & 4 & 5 & 6 & 7 & 8 & 9 \\
\hline Surface & 1 & 8 & 66 & 1 & - & - & 3 & - & - \\
\hline II & - & 4 & 67 & 1 & - & 4 & 39 & 2 & \\
\hline III & 4 & 7 & 58 & 9 & 4 & 3 & 21 & 5 & \\
\hline IV & 4 & 5 & 24 & 11 & 1 & 12 & 23 & 6 & \\
\hline $\mathrm{V}$ & 10 & 7 & 29 & 12 & 2 & 8 & 36 & 10 & \\
\hline VI & 3 & 4 & 12 & 28 & 8 & 7 & 39 & 25 & \\
\hline
\end{tabular}

GADID $A$.

Gadus merlangus L.

In the collections in 1924, only one post-larval whiting occurred : this was taken at 7 metres at dusk.

In June, 1925, they were more numerous, but the results (see Table 8, p. 398) do not point to any definite migration at night; however, while none were taken right on the surface in the daytime, one or two were taken there by the dusk, midnight, and dawn hauls. Nearly all the specimens were between 7 and $20 \mathrm{~mm}$. in length. The following table 
shows the numbers of larger specimens taken, ranging between 22 and $50 \mathrm{~mm}$. in length.

$\begin{array}{cccccccccc}\text { Series } & 1 & 2 & 3 & 4 & 5 & 6 & 7 & 8 & 9 \\ \text { Surface } & - & - & - & 1 & - & - & - & 1 & - \\ \text { II } & - & - & 1 & 3 & - & - & - & 1 & - \\ \text { III } & - & - & - & 1 & - & - & - & - & - \\ \text { IV } & - & - & - & - & - & - & - & 6 & - \\ \text { V } & 1 & 1 & - & 1 & - & - & - & 2 & - \\ \text { VI } & 2 & - & - & - & - & - & - & - & -\end{array}$

It will be seen that the larger number of young whiting of this size were taken at dawn on both days, when they occurred at most depths; including the surface. At each of the depths IV and V in series 8 one small Cyanea capillata was captured.

\section{Gadus minutus (O. F. Müll.).}

Post-larvæ of Gadus minutus were very scarce on both occasions; however the results would point to quite a definite upward movement on the part of some at night. On July 15th-16th, 1924, two specimens only were captured, 14 and $12 \frac{1}{2} \mathrm{~mm}$. in length. The first of these was taken at 32 metres at 7.56 p.m., and the other at the same depth at 10.52 p.m. ; none occurred in any of the daylight or dawn hauls.

On June 17th, 18th, and 19th, 1925, specimens, $6 \frac{1}{2}-12 \mathrm{~mm}$. in length, were taken in the hauls shown in the following table.

$\begin{array}{cccccccccc}\text { Series } & 1 & 2 & 3 & 4 & 5 & 6 & 7 & 8 & 9 \\ \text { Surface } & - & - & - & - & - & - & - & - & - \\ \text { II } & - & - & 2 & - & - & - & - & - & - \\ \text { III } & - & - & 1 & - & - & - & 1 & - & - \\ \text { IV } & - & 1 & 1 & - & - & - & 1 & - & - \\ \text { V } & - & 6 & 3 & - & - & - & 4 & - & - \\ \text { VI } & - & 2 & - & 1 & - & - & 1 & 1 & -\end{array}$

Here we see definite indications that the post-larvæ were extending their distribution upwards at dusk and midnight on the first night, and at midnight on the second night, reaching a level at a depth of 11 and 12 metres respectively, at which depth it is very unusual to meet with them in the daytime ( $\boldsymbol{y}$, p. 119). 


\section{BOTHID Æ.}

\section{ARnoglossus SP.}

On July 15th-16th, 1924, at 3.44 p.m. one post-larva only of Arnoglossus, probably $A$. laterna (Will.), was taken at $19.5 \mathrm{~m}$. ; at 8.15 p.m. one at $17.1 \mathrm{~m}$. ; at midnight eleven were caught at the surface, and one or two at every other depth sampled; at $4 \cdot 6$ a.m. none were taken quite at the surface, but four at $1.9 \mathrm{~m}$., nine at $9 \mathrm{~m}$., and three and two at 16 and $30 \mathrm{~m}$. respectively. In daylight the next day none were caught at the surface or at 5 metres, but five, three, and one were taken at 12.5 , $18 \cdot 3$, and $31 \cdot 1 \mathrm{~m}$. respectively. Thus it would appear that this species showed quite a definite migration towards the surface at midnight, together with a total increase in numbers.

In 1925, on June 17th, between 2.30 and 4.20 p.m., no Arnoglossus post-larvæ were taken; at 8.53 p.m. one only was taken at a depth of $5 \cdot 4$ metres, and at midnight one at the surface; in the next two series, dawn and daylight, on the 18th, none were caught, but at dusk between 7.30 and 9.6 p.m. one was taken at each of the following depths: surface, $9.3 \mathrm{~m} ., 19.4 \mathrm{~m}$., and $30.9 \mathrm{~m}$. ; between $10.30 \mathrm{p} . \mathrm{m}$. and 12 midnight one occurred at $12 \cdot 2 \mathrm{~m}$., one at $16 \cdot 6$, and one at $20 \cdot 7 \mathrm{~m}$. In the two following series, at dawn and daylight on the 19th, again no specimens were captured. Thus on this occasion also there occurred an increase in numbers in the darker hours, possibly indicating an upward movement.

\section{Scophthalmus norvegicus (Günther).}

The numbers of $S$. norvegicus post-larvæ, all between 4 and $10 \frac{1}{2} \mathrm{~mm}$. in length, taken on July 15th-16th, 1924, are given below.

\begin{tabular}{|c|c|c|c|c|c|}
\hline & $\begin{array}{l}\text { 1st Series. } \\
3.25 \text { p.m. to } \\
4.45 \text { p.m. }\end{array}$ & $\begin{array}{l}\text { 2nd Series. } \\
7.55 \text { p.m. to } \\
9.17 \text { p.m. }\end{array}$ & $\begin{array}{l}\text { 3rd Series. } \\
10.50 \text { p.m. to } \\
12.20 \text { a.m. }\end{array}$ & $\begin{array}{l}\text { 4th Series. } \\
2.50 \text { a.m. t) } \\
4.16 \text { a.m. }\end{array}$ & $\begin{array}{l}\text { 5th Series. } \\
8.45 \text { a.m. to } \\
10.11 \text { a.m. }\end{array}$ \\
\hline Surface & - & 5 & 1 & - & - \\
\hline II, $2-7$ m. & 1 & 8 & 2 & 2 & - \\
\hline III, 9-15 m. & 10 & 3 & 5 & 2 & 2 \\
\hline $\mathrm{IV}, 16-20 \mathrm{~m}$. & 37 & 25 & 4 & 4 & 14 \\
\hline V, 30-34 m. & 1 & 13 & 9 & 12 & 8 \\
\hline
\end{tabular}

These figures show that while in the daytime these post-larvæ appeared to avoid the water layers between the surface and a depth of about 13 metres, at night they extended their distribution upwards, so that a few occurred at the surface itself; the greater number, however, still kept to the deeper layers. 
From June 17th to 19th in 1925 we again see a similar behaviour, although in this case the numbers of individuals captured are small (Table 8, p. 398); on the second night the majority occurred, as in 1924, below a depth of 10 metres, and on the first night the largest catch was from $11 \mathrm{~m}$., but the numbers taken on this night were very small.

\section{PLEURONECTID $Æ$.}

\section{Pleuronectes microcephalus (Don.).}

On July 15th-16th, 1924, post-larvæ of P. microcephalus, 6-12 mm. in length,* occurred in daylight, at dusk, at dawn, and again in daylight, only below 15 metres, except for one at 9 metres at 3.34 a.m. In the dark, however, between 10.52 p.m. and 12.9 a.m. they were distributed from the surface downwards (see Table 7, p. 397).

In June, 1925, there was evidence that they extended upwards at dusk and remained so at midnight, on both nights on which the collections were taken, but they never actually reached the surface. They were all between $5 \frac{1}{2}$ and $12 \frac{1}{2} \mathrm{~m}$. long. In the daytime none were caught above 20 metres; there is again evidence of a slight increase in numbers at night, possibly indicating that in the daytime they were restricted to some deep-lying zone not sampled by the net (Table 8, p. 398).

\section{SOLEID Æ.}

\section{Solea variegata (Don.).}

Post-larvæ, 4 to $8 \frac{1}{2} \mathrm{~mm}$. in length, of $S$. variegata, were only taken throughout the period of collecting on July 15th-16th, 1924, below 10 metres, except at 8.49 p.m., when five were caught at a depth of 7 metres; this time, however, the majority still occurred below 10 metres (Table 7, p. 397). There was therefore little indication of change in vertical distribution throughout the night.

Again on June 17th to 19th, 1925, they mostly occurred below 10 metres. There was a slight indication of extension upwards of their distibution at midnight on the 18th, when three were caught at the surface, at this time, though, they were again more abundant in the deeper layers (see Table 8, p. 398).

\section{CARANGID $\AA$.}

\section{Caranx trachurus (L.).}

Post-larvæ of Caranx trachurus, between 4 and $8 \mathrm{~mm}$. in length, were taken on July 15th-16th, 1924 ; while the largest catch was made at

* At 11.16 p.m. at $20 \cdot 7$ metres one metamorphosing specimen $16 \frac{1}{2} \mathrm{~mm}$. in length was captured, and at $31 \mathrm{~m}$. at $8.46 \mathrm{a} . \mathrm{m}$. a late post-larva of $14 \frac{1}{2} \mathrm{~mm}$. 
13.6 metres at 4 p.m. on July 15 th, at 11.52 p.m. most were caught at $5 \cdot 8 \mathrm{~m}$., and at 3.34 a.m. on July 16 th the majority were taken at $9 \mathrm{~m}$. (Table 7, p. 397). In June, 1925, none were taken.

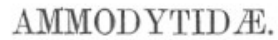

\section{Ammodytes lanceolatus (Lesauv.).}

Post-larvæ of Ammodytes lanceolatus, mostly between 5 and $20 \mathrm{~mm}$. in length, showed on the night of July 15th, 1924, no very marked increase in numbers in the surface layers. At this time there was a full moon. From Fig. 5 it would appear that they moved slightly downwards at dusk, and that at midnight they were evenly distributed between the depths of 10 and 30 metres, avoiding the layers from the surface down to 5 and 6 metres, although there were relatively more at this level than in the daytime. In the daytime they were most abundant below a depth of about 15 metres.

The following table gives the sizes and total numbers of specimens taken in each haul of the five series :-

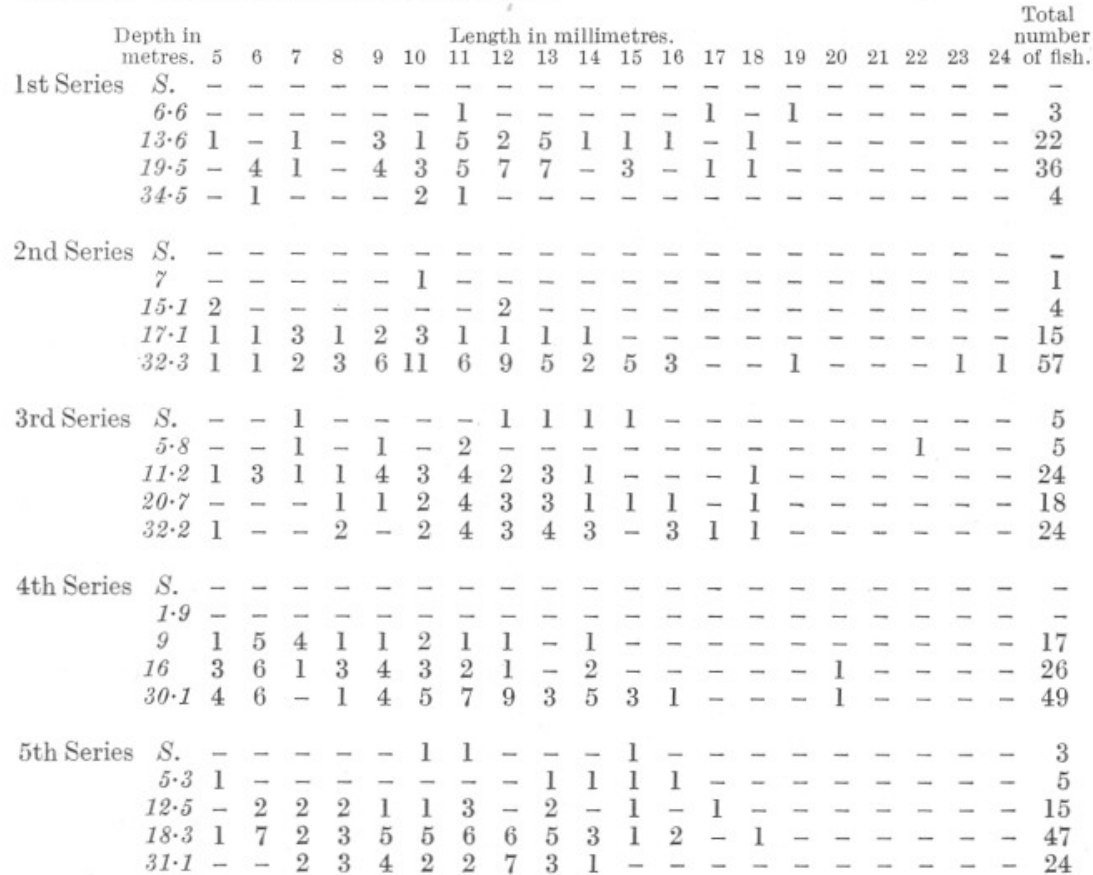

In the collections on June 17th-19th, 1925, very few post-larval stages of this species occurred. The numbers were too small to show any indication of movement (Table 8, p. 398). 
Johansen (4, p. 11) gives records of this species for April in Danish waters, which show a huge increase in the numbers taken at night over those caught in the daytime. It is noteworthy, however, that these stages were from 13 to $91 \mathrm{~mm}$. in length, very much larger than the specimens I have taken, and it is more than probable that at this length the young sand-eels are congregated together in shoals and have already

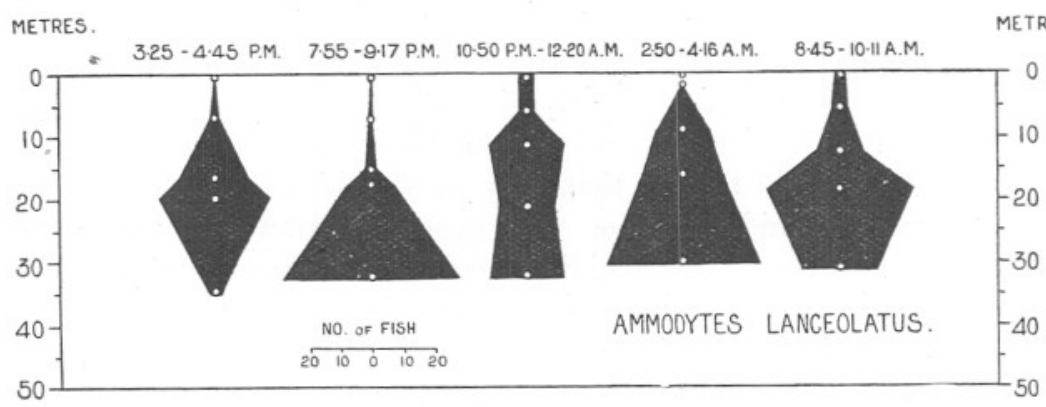

FIG. 5.-The vertical distribution of Ammodytes lanceolatus post-larvæ, at the times shown on July 15th-16th, 1924. The white spots and black circles indicate the " average depths" at which hauls were taken.

adopted their typical habit of burrowing in the sand, in which case they may well have been either in the deeper layers or buried in the bottom in the daytime. Further, the extraordinary rapidity with which these fish can move, a whole swarm dispersing with lightning speed, would enable them to avoid the net in daylight. At this stage, in our waters, they are mostly quite close inshore, when on clear days one can see the large swarms swimming about over sandy bottoms near the rocks; a sudden movement on the part of the observer or the casting of a stone into the water will disperse the shoal immediately.

\section{CALLIONYMID $Æ$.}

\section{Callionymus sp.}

The specimens captured on these occasions were mostly the postlarvæ of Callionymus lyra (L.). A few C. maculatus (Rafin.) were, however, present. Of the large number taken on July 15th-16th, 1924, only twenty-five specimens of $C$. maculatus were seen; these were specimens in a sufficiently advanced stage of development to be distinguishable from C. lyra by the pigmentation of the ventral fin (Fage 3, p. 136, and Mielck 5, p. 232). It is possible that a few earlier stages may also have been present. In June, 1925, probably the post-larvæ of $C$. maculatus were even more scarce, e.g. among the 248 specimens taken at 7.27 p.m. on June 17th from 38.6 metres none were seen. 
On July 15th-16th, 1924, at the period of full moon, the post-larvæ of Callionymus sp. showed no signs of making any upward movement during the night. An examination of Table 11 and also of Fig. 6, which gives diagrammatically the distribution at different times, shows that there was even an indication that the young Callionymus went deeper

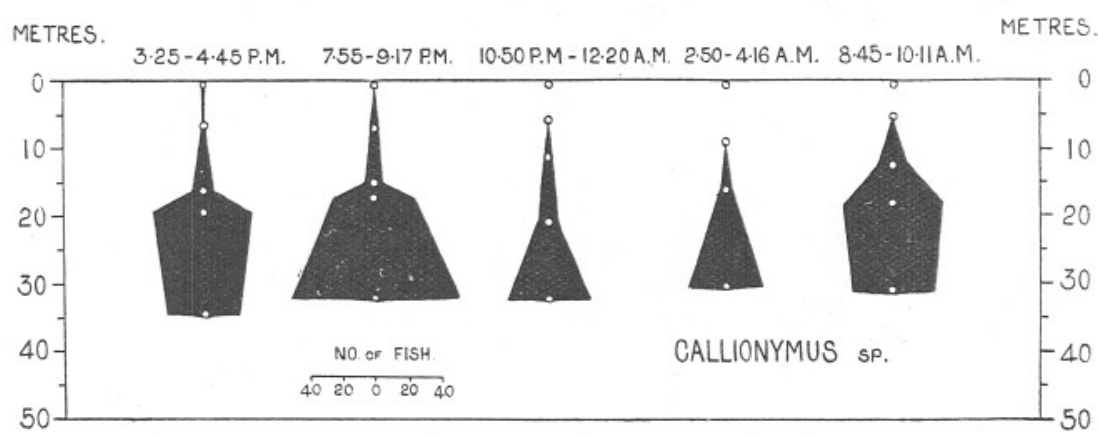

Fig. 6.-The vertical distribution of Callionymus sp. post-larvæ, at the times shown on July 15th-16th, 1924. The white spots and black circles indicate the "average depths" at which hauls were taken.

during the night and early hours of the morning than in the daytime. In the afternoon and at dusk on July 15th and in full daylight on the morning of July 16th there was a sudden increase in the numbers of these post-larvæ below 15 metres, and above this level very few were taken; at midnight and dawn, however, they were relatively scarce even down to a depth of 20 metres.

\section{TABLE 11.}

Numbers of Post-Larve of Callionymus sp. in each Haul on JuLY 15TH-16TH, 1924.

$\begin{array}{lccccc} & 4.45 \text { p.m. } & 9.17 \text { p.m. } & 12.20 \text { a.m. } & 4.16 \mathrm{a} . \mathrm{m} . & 10.11 \mathrm{a} . \mathrm{m} . \\ \text { Surface } & 2 & - & 3 & - & - \\ \text { II, } 2-7 \mathrm{~m} . & 3 & 7 & 1 & - & 2 \\ \text { III, } 9-15 \mathrm{~m} . & 14 & 12 & 6 & 2 & 19 \\ \text { IV }, 16-20 \mathrm{~m} . & 62 & 47 & 12 & 8 & 59 \\ \text { V, } 30-34 \mathrm{~m} . & 42 & 101 & 71 & 44 & 50\end{array}$

In the two daylight series (1 and 5) and the dusk series (2) all the postlarvæ were between 3.5 and $7.5 \mathrm{~mm}$. in length. At midnight, however, at 20.7 metres, three specimens, $8 \mathrm{~mm}$. long and two of 8.5 and 9.5 respectively, were caught; while in the same series at $32 \cdot 2$ metres there were four $8 \mathrm{~mm}$. long and two bottom-stages of 12.5 and $14 \mathrm{~mm}$. At dawn at 30 metres two $9.5 \mathrm{~mm}$. and one $10 \mathrm{~mm}$. long were caught; these 
were very early bottom stages, one of which was a $C$. maculatus. This is an indication of an upward movement from the deeper layers of the older stages.

On the two nights in June, 1925, when there was no moon, there was apparently definite evidence of a vertical movement upwards at night (see Table 12 and Fig. 7). In the daylight hardly a single specimen was

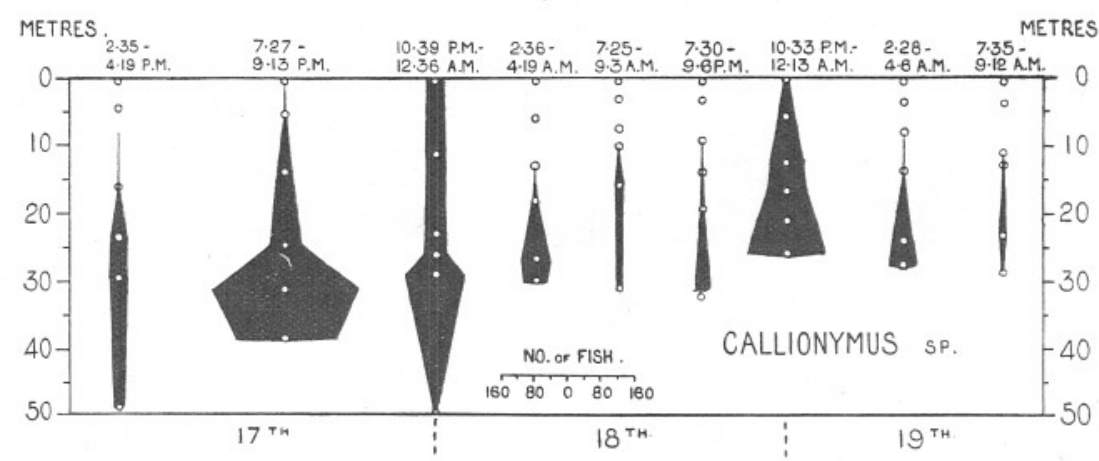

FIG. 7.-The vertical distribution of Callionymus sp. post-larvæ, at the times shown, on June 17th-18th-19th, 1925, showing the increase in numbers at all depths on the two nights. The white spots and black circles indicate the "average depths" at which hauls were taken.

taken in any of the hauls above 15 metres, but at night post-larvæ were caught at the surface itself, although they were apparently still far more numerous in the deeper layers.

TABLE 12.

Numbers of Post-larve of Callionymus sp. in each Haul on JUNE $17 \mathrm{TH}-18 \mathrm{TH}-19 \mathrm{TH}, 1925$.

$\begin{array}{lrrrrrrrrr}\text { Series } & 1 & 2 & 3 & 4 & 5 & 6 & 7 & 8 & 9 \\ & & & & & & & & & \\ \text { Surface } & 1 & 1 & 38 & 1 & - & - & 12 & - & - \\ \text { II } & 1 & 10 & 47 & 1 & - & 1 & 41 & 2 & - \\ \text { III } & 6 & 39 & 52 & 5 & 2 & - & 79 & 4 & - \\ \text { IV } & 40 & 85 & 59 & 17 & 2 & 8 & 96 & 6 & 11 \\ \text { V } & 45 & 352 & 145 & 71 & 26 & 9 & 147 & 59 & 21 \\ \text { VI } & 30 & 248 & 5 & 54 & 18 & 31 & 182 & 75 & 9\end{array}$

Again, as we noticed to be the case with the pilchard post-larvæ, we find a curious increase in the total number of young Callionymus caught at night in June, 1925. To show that this is not due to a vertical movement of fish of the small bottom-living stages I append the following 
figures, giving the actual sizes of the specimens taken in two of the hauls : at 29.8 metres in Series 1 and 31.3 metres in Series 2 . It will be seen that in neither case can any of these be said to be true bottom living forms, but that they are all true planktonic post-larvæ. Ehrenbaum (2, p. 106) says that Callionymus lyra takes to the bottom at a length over $10 \mathrm{~mm}$., and Mielck (5, p. 235) gives about 11-12 mm. for the corresponding stage of development of C. maculatus (?).

\begin{tabular}{|c|c|c|c|c|c|c|c|c|c|c|c|c|}
\hline \multicolumn{13}{|c|}{ Length in millimetres. } \\
\hline & 4 & $4 \frac{1}{2}$ & 5 & $5 \frac{1}{2}$ & 6 & $6 \frac{1}{2}$ & 7 & $7 \frac{1}{2}$ & 8 & $8 \frac{1}{2}$ & 9 & $9 \frac{1}{2}$ \\
\hline 1st Series, 29 . & - & 3 & 10 & 9 & 7 & 4 & 3 & 2 & 3 & 3 & 1 & - \\
\hline $31 \cdot 3 \mathrm{~m}$ & 3 & 15 & 51 & 29 & 58 & 42 & 58 & 37 & 36 & 13 & 8 & - \\
\hline
\end{tabular}

The possible explanations for this increase in numbers will be the same as those already stated under the description of the vertical distribution of Sardina pilchardus post-larvæ (p. 401). Perhaps, judging from the actual figures which show such a large increase in the deeper layers at night, it is most probable that in mid-June, a time at which the light is at its strongest and its penetration into the water probably deepest, the Callionymus larvæ were, in the daytime, congregated either in the water layer a few metres above the bottom or actually resting on the bottom itself. The figures for daytime catches shown in Tables 6 and 8 , pp. 155 and 157, of a previous paper ( $\mathbf{y})$ would indicate that on June 4th and July 1st these post-larvæ occurred higher in the water. Tables 3 and 4 , pp. 152 and 153 , of the same paper show, however, that in midJune, 1924, on the 17th and 25th days of the month, in the daytime they were also well above the bottom; on both these dates the weather was dull. In June, 1925, the amount of sunshine recorded in the Southwest of England was exceptional, and may well have been the cause of the fish seeking the deepest layers, if such should turn out to be a correct interpretation of the figures shown by my collections. I give below the figures showing the average daily sunlight for the weeks at this time of year in 1924 and 1925 .

\begin{tabular}{|c|c|c|c|c|c|}
\hline & & & $\mathrm{Av}$ & age nu & ours $\mathrm{p}$ \\
\hline & & & & 1924 & 1925 \\
\hline 22 nd & eek & th & rear & $5 \cdot 2$ & $12 \cdot 1$ \\
\hline $23 \mathrm{rd}$ & , & ", & ," & $2 \cdot 2$ & $12 \cdot 6$ \\
\hline 24th & , & , & , & 6.5 & $10 \cdot 6$ \\
\hline 25th & , & , & , & $6 \cdot 7$ & $9 \cdot 7$ \\
\hline 26th &, &, & , & $4 \cdot 4$ & $7 \cdot 9$ \\
\hline
\end{tabular}

Atkins, in a paper on Phosphate Content in this volume of this Journal (1), gives on p. 457 a graph that illustrates this exceptional amount of sunshine in June, 1925. 


\section{LABRID $\nexists$.}

Post-larval wrasses were scarce on June 17th-19th, 1925; but on July 15th-16th, 1924, young Ctenolabrus rupestris, Crenilabrus melops, and Centrolabrus exoletus were present throughout the series. It has been shown $(\%$, p. 131$)$ that these forms are somewhat irregular in their vertical distribution, and may be taken right at the surface in daylight; little information can be obtained from the figures (Table 7, p. 397), except that at any rate they did not definitely migrate to the surface at night in which case they would have been taken in greatest numbers at that region.

\section{SCOMBRID AE.}

\section{Scomber scomber (L.).}

The post-larvæ of the mackerel have been shown to occur as much in the upper layers as deeper down in the daytime, even being taken right on the surface ( $(\%$, p. 133$)$.

On July 15th-16th, 1924, they were most abundant at 5 or 6 metres in the two daylight hauls and at midnight; at dusk and dawn, however, they would seem to have been deeper in the water, between 9 and 17 metres. This may, of course, be due to uneven horizontal distribution, because while at dusk on June 18th, 1925, they were mostly at 20 to 30 metres, at dusk on the 17 th there was no indication of this.

\section{GOBIID Æ.}

\section{Gobius elongatus Canest.}

Post-larvæ of Gobius elongatus on July 15th, 1924, showed a distinct extension of their distribution into the upper and surface layers at night. An examination of Table 13 and of Fig. 8, however, will show that the bulk of the young fish were still well below the actual surface.

TABLe 13.

\section{Numbers of Gobius elongatus post-Larva in each Haul on JuLy $15 \mathrm{TH}-16 \mathrm{TH}, 1924$.}

Surface

II, $2-7 \mathrm{~m}$.

III, $9-15 \mathrm{~m}$.

IV, $16-20 \mathrm{~m}$.

$\mathrm{V}, 30-34 \mathrm{~m}$. 1st Series, 2nd Series, 3rd Series, 4th Series, 5th Series. 3.25 p.m. to 7.55 p.m. to 10.50 p.m. to 2.50 a.m. to 8.45 a.m. to 4.45 p.m. $\quad 9.17$ p.m. $\quad 12.20$ a.m. $\quad 4.16$ a.m. $\quad 10.11$ a.m.

$\begin{array}{rrrrr}1 & 15 & 23 & 4 & 2 \\ 9 & 89 & 52 & 26 & 10 \\ 68 & 154 & 87 & 237 & 103 \\ 06 & 171 & 95 & 213 & 236 \\ 62 & 118 & 210 & 187 & 105\end{array}$


It is curious that in the 3rd Series (Dark) the largest catch was made by the bottom haul, as with Callionymus (p. 407), indicating a possible descent of some individuals (see Fig. 5) ; no conclusion, however, can be drawn from a single observation, unevenness in horizontal distribution always having to be borne in mind.

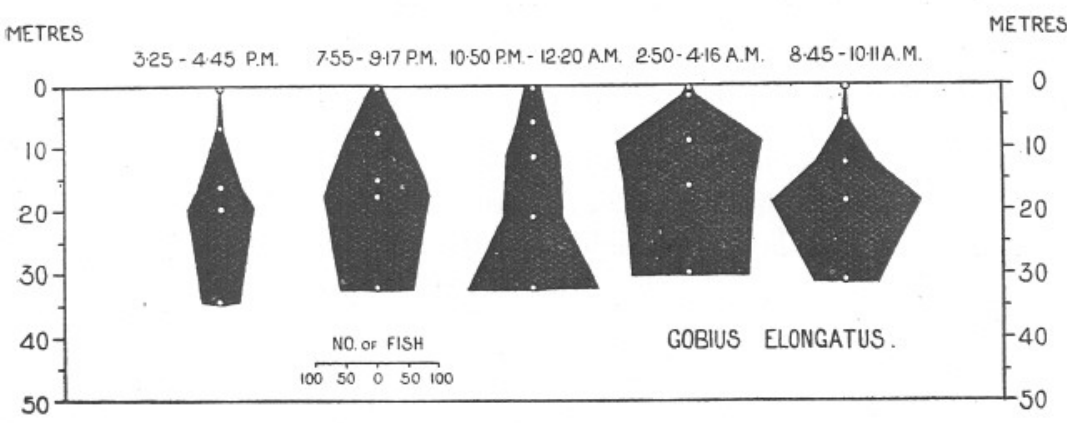

FIG. 8.- The vertical distribution of Gobius elongatus post-larvæ, at the times shown, on July 15th-16th, 1924. The white spots and black circles indicate the "average depths" at which hauls were taken.

In June, 1925, post-larval Gobies were extremely scarce in the daytime ; at night, however, there was a marked increase in numbers at all depths, and they appeared to have been fairly evenly distributed from the surface downwards (Table 8, p. 398).

\section{Lebetus SCORPIOIDES (Coll.).}

Post-larvæ of Lebetus scorpioides were extremely rare on both the occasions on which serial collections were made.

On July 15th, 1924, in Series 1 two only were taken, one from a depth of $19.5 \mathrm{~m}$. and the other from $34.5 \mathrm{~m}$. In Series 2 no specimens were captured. In Series 3 one was taken at the surface, one at $5.8 \mathrm{~m}$., and two at $32 \cdot 2 \mathrm{~m}$. In Series 4 only one was caught, and that from $30 \cdot 1 \mathrm{~m}$. ; and in Series 5 two were taken, both from $18.3 \mathrm{~m}$. In June, 1925, none were taken, except at 8.11 p.m. and 10.55 p.m. on the second night, June 18th, when they were caught at 14 and $20 \cdot 7$ metres respectively (Table 8, p. 398).

Johansen, in April, 1925, only took this species in the upper water layers, in Danish waters, between the hours of 12 midnight and 2 a.m. (4, p. 10). 


\section{BLENNIID E.}

Blennius pholis (L.) and Blennius ocellaris (L.).

Post-larvæ of Blennius pholis and Blennius ocellaris were too scarce on both occasions to show any evidence of their behaviour (Tables 7 and 8 , p. 397).

\section{Blennius gattorugine (L.).}

Blennius gattorugine post-larvæ did not avoid the upper layers in the daytime on July 15th-16th, 1924; there is an indication of an accumulation in the surface layers at night, but the numbers are too small to be conclusive. In June, 1925, they were very scarce.

\section{TRIGLID $\nRightarrow$.}

Trigla sp.

In July, 1924, post-larvæ of Trigla sp., which were living in the daytime below a depth of about 7 metres, showed a slight extension upwards of their vertical distribution at dusk, dark, and dawn, but on no occasion was any specimen caught at the surface itself (Table 7, p. 397). On the two nights in June, 1925, however, when there was no moon, although the numbers taken were very small, there is an indication of a more marked upward movement (Table 8, p. 398).

\section{GOBIESOCID $\approx$.}

\section{Lepadogaster bimaculatus (Penn.).}

In July, 1924, post-larvæ of L. bimaculatus showed no signs of any diurnal change in their vertical distribution, being taken mostly below 20 metres; one was taken at $7 \mathrm{~m}$. at dusk. In June, 1925, only seven specimens were caught in the whole series of collections; of these two were taken in daylight, three in the dark, and two at dawn.

\section{CYCLOPTERID Æ.}

\section{Liparis Montagui (Donov.)}

Only two post-larvæ of L. montagui occurred in the July, 1924, collections; one was taken at 8.15 p.m. from 17 metres and one at 10.52 p.m. from $32 \mathrm{~m}$. There were none caught in June, 1925. 


\section{AGONID无.}

\section{Agonus cataphractus.}

In all the collections one post-larvæ of this species only occurred; this was from 25 metres at 10.33 p.m. on June 18th, 1925.

\section{LOPHIID $Æ$.}

\section{LOPHIUS PISCATORIUS (L.).}

Post-larval L. piscatorius only occurred in June, 1924, when only seven specimens were taken altogether; there was no evidence of upward movement at night (Table 7, p. 397).

\section{SUMMARY.}

1. Results are given of collections made with the stramin ring-trawl to study the vertical distribution of post-larval teleostean fishes throughout the period from daylight, through the hours of darkness, to daylight on July 15th-16th, 1924, and June 17th, 18th, and 19th, 1925. At the time of collecting in July, 1924, it was full moon ; in June, 1925, there was no moon.

2. In no case, except perhaps that of Sardina pilchardus post-larvæ, was there evidence of marked upward migration at night ; the general impression for most species was that while the type of distribution shown in daylight was somewhat modified at night, only very few individuals moved up to the surface layers. There was, however, a notable increase in numbers of certain species at all depths at night, whether this was an indication of a movement up from layers very close to the bottom is not known ; it will need many more observations before the exact significance of this can be fully understood.

3. The numbers of post-larvæ taken were in the case of most species unfortunately very small on all occasions; it is not possible, therefore, to come to very definite conclusions.

4. A possible indication of the effect of moonlight was shown by the post-larval Callionymus lyra, for while in July, 1924, at the time of full moon they showed no upward movement at night, in June, 1925, with no moon a certain proportion reached the surface layers. 


\section{LITERATURE CITED.}

1. Atkins, W. R. G. The Phosphate Content of Sea-water in Relation to the Growth of Algal Plankton. Part III. Journ. Mar. Biol. Assoc., N.S., Vol. XIV, No. 2. 1926.

2. Ehrenbaum, E. Eier und Larven von Fischen. Nordisches Plankton. Vierte Lieferung. 1905 .

3. Fage, L. Shore Fishes. Rep. Danish Ocean. Exped., 1908-1910 No. 4, p. 132.1918.

4. Johansen, A. C. On the Diurnal Vertical Movements of Young of some Fishes in Danish Waters. Medd. fra Komm. for Havundersogelser. Serie Fiskeri., Bd. VIII, Nr. 2. 1925.

5. Mielck, W. Heringslarven, Eier und Larven anderer Fische und Nahrung der Larven in der westlichen Nordsee im Oktober, 1922. Berichte der Deutsch. Wissenschaft Komm. für Meeresforch., N.F., Bd. I (1919-1923), No. VII, p. 231.

6. Russell, F. S. The Vertical Distribution of Marine Macroplankton. An observation on Diurnal Changes. Journ. Mar. Biol. Assoc., N.S., Vol. XIII, No. 4. 1925.

7. Russell, F. S. The Vertical Distribution of Marine Macroplankton. II. The Pelagic Young of Teleostean Fishes in the Daytime in the Plymouth area, with a note on the eggs of certain Species. Journ. Mar. Biol. Assoc., N.S., Vol. XIV, No. 1, p. 101. 1926. 